\title{
A Study on Learners' Needs Analysis in Curriculum Setting Based on College English Curriculum of Non-English Major Students
}

\author{
Sisi Hu \\ Nanchang Institute of Science \&Technology, Nanchang Jiangxi 330108, China
}

Keywords: learners' needs, curriculum setting, college English, curriculum objectives, curriculum content, curriculum implementation.

\begin{abstract}
Curriculum setting is a dynamic system, which is composed of curriculum objectives, content, implementation and evaluation. Learners' needs is one of its key sources. By means of a questionnaire survey among non-English major students, this study finds students of different genders, language proficiencies and majors have significant differences in their college English curriculum needs of its objectives, content and implementation: (1) female students have significantly stronger needs in curriculum objectives, content, implementation than male students; (2) high level proficiency students' needs of abundant and pluralistic curriculum content are significantly stronger than low level proficiency students; (3) there are significant differences among students with different majors in their needs of curriculum objectives and content.
\end{abstract}

\section{Introduction}

Under the background of economic globalization, the society has been putting forward higher requirements for the talent. As for college English teaching, colleges and universities teachers should concentrate more on cultivating students' abilities of applying English to practical communication, improving students’ autonomous English learning ability, developing computer network teaching and so on. Among them, what matters most is to change the main objective of curriculum setting into the combination of language skills and professional knowledge, that is to say, train comprehensive and even outstanding English talents for the society.

Despite the fact that college English teaching reform adapted to the development of times, this top-down model partially ignored students' internal needs. Therefore, the inspiration for conducting the present study comes from three questions, which is frequently raised by students, teachers and 
researchers in the field of foreign language learning and teaching: Why should the students take college English courses? What kind of English courses do they really need? What can we do to adjust curriculum setting to meet the students’ needs?

\section{Theoretical Background}

Curriculum setting is a dynamic system formed by curriculum objectives, content, implementation and evaluation instead of the superposition of lesson types in brief. Hutchinson and Waters proposed needs analysis in ESP / LSP (English / Language for Specific Purposes) teaching, then this theory were applied to EGP (English for General Purposes) teaching. In order to make curriculum setting more scientific and reasonable, Richterich and Chancerel designed needs analysis patterns to explore how to meet the communicative needs of foreign language learners in different situations. Under the influence of curriculum development, some foreign scholars and researchers shed light on the distinction of learners' needs from the perspective of individual, society, etc (Hutchinson \& Waters, 1987; Dudley-Evans \& St John, 1988).

Learners' needs refers to the differences between students' actual learning abilities and the abilities they want to achieve, which can be employed to know about students' language proficiencies before taking foreign language courses and investigate their language advantages and disadvantages, learning attitudes, learning preferences, needs and expectations (Dudley-Evans \& St John, 1988).

Taking these needs analysis as bases, many studies on curriculum setting were carried out by researchers in China. Yang Xiaobing (2013) conducted a questionnaire survey about non-English major students' needs analysis of college English curriculum, the results indicated college English teaching should pay more attention on curriculum setting during the transformation and construct curriculum system to cultivate talents in accordance with social needs. Liu Yanmei and Zhu Huimin (2013) carried out a study among students of different majors, found out most of the students thought their needs were not fully met in current college English teaching and the differences among students with different majors and different language proficiencies in their needs of college English curriculum are significant. 
Although a lot of needs analysis researches either abroad or at home have been done and some achievements have been made, fewer studies have taken the gender or language proficiency differences related to learners' needs into consideration. Thus, the present study aims to do more in-depth studies in this area. Moreover, the results of the study will show the students' needs to college English teachers and provide some suggestions for enhancing learners' needs in English teaching and learning.

\section{Research Methodology}

The subjects in this study are 568 non-English major students from freshman to sophomore with approximately equal proportions of men and women from sixteen different departments in a university in Jiangxi Province. Among them, male students are 353, female students are 215, with age ranging from 17 to 22. Three homogeneous groups, which are particularly in the specialities of arts, management, science and technology, are based on the subjects' scores in the entrance proficiency test of English, students in the top 20 percent are classified as Group A, while those in the last 20 percent are in Group C, and the rest 60 percent of students are classified as Group B. Table 1 gives a brief introduction of subjects’ basic information.

Table 1. The General Description of the Subjects

\begin{tabular}{|c|c|c|c|}
\hline \multirow{2}{*}{ Category } & Number & Percentage (\%) \\
\hline \multirow{3}{*}{ Gender } & Male & 353 & 62.1 \\
\cline { 2 - 4 } & Female & 215 & 37.9 \\
\hline \multirow{3}{*}{ Grade } & Freshman & 297 & 52.3 \\
\cline { 2 - 4 } Major & Sophomore & 271 & 47.7 \\
\cline { 2 - 4 } & Science and Technology & 153 & 26.9 \\
\cline { 2 - 4 } & Management & 218 & 38.4 \\
\hline \multirow{2}{*}{$\begin{array}{c}\text { Proficiency } \\
\text { (Group) }\end{array}$} & Group A & 197 & 34.7 \\
\cline { 2 - 4 } & Group B & 36 & 65.9 \\
\cline { 2 - 4 } & Group C & 101 & 17.7 \\
\hline
\end{tabular}

Instrument. The instrument employed in the study is a self-designed questionnaire, which was mostly adopted from Dudley Evans and St John's analytical framework of needs analysis (1998) and Wang Haixiao's analytical model of needs analysis (2004). The items in the questionnaire are 
weighed up by a five-point Likert sacle from "strongly disagree" to "strongly agree" (1=strongly disagree, 5=strongly agree). In terms of curriculum objectives, content, implementation, evaluation and learners' self-assessment of English skills, they are adopted to investigate learners' needs in English curriculum. The questionnaire attempts to cover as many factors as possible for English learners' needs in curriculum setting.

Data-collection and Data-analysis. Altogether 593 questionnaires were distributed and 568 valid questionnaires were collected for the study. Because 25 students were not finished as required, their questionnaires were regarded as invalid. Therefore, the collection rate is $95.8 \%$. Meanwhile, SPSS was used to analyze all descriptive statistics and the differences in the results.

\section{Results and Discussion}

General Tendency of Learners' Needs in Curriculum Setting. The study explores the needs of different genders, language proficiencies and majors in college English curriculum by non-parametric test (Mann-Whitney test and Kruskal-Wallis H (K) test). And Mean Rank (MR) can be used to find differences between samples. The higher the MR values, the greater the needs are asked. As can be seen from Table 2, the results show that there are significant differences among learners' needs of students with different genders, proficiencies and majors in college English curriculum.

Table 2. Differences Among Learners’ Needs of Students with Different

Genders, Grades, Proficiencies and Majors in College English Curriculum

\begin{tabular}{|c|c|c|c|c|}
\hline & $\mathrm{N}$ & $\mathrm{SD}$ & $\mathrm{Z} / \mathrm{X}^{2}$ & $\mathrm{P}$ \\
\hline Gender & 568 & .355 & -6.459 & $.0001^{* *}$ \\
\hline Grade & 568 & .613 & 1.107 & .436 \\
\hline Major & 568 & .392 & 27.524 & $.0001^{* *}$ \\
\hline Proficiency (Group) & 568 & 2.978 & 18.035 & $.021^{*}$ \\
\hline
\end{tabular}

$(* \mathrm{P}<.05 ; * * \mathrm{P}<.01)$

Differences in Learners' Needs between Male and Female Students. The needs of curriculum objectives are learners' expectations for the curriculum and their own learning goals and hopes, which can reflect learners' motivation level in English study. Learners' needs of curriculum 
objectives, actually, are bases for their learning motivations, which also have a positive correlation with them. What's more, they are driving forces to stimulate learners' needs of curriculum content and implementation. In addition to curriculum evaluation, the results in Table 3 reveal that the differences between male students and female students in the needs of college English curriculum objectives, content and implementation are very clear $(\mathrm{P}=0.000)$. And those needs for females (MR: 1376.53/1398.85/1359.43/1289.82) are obviously stronger than males (MR: 1124.21/1087.60/1165.87/1274.55).

Table 3. Differences in Learners’ Needs between Male and Female Students in College Curriculum Objectives, Content, Implementation and Evaluation

\begin{tabular}{|c|c|c|c|c|c|}
\hline Curriculum & Gender & MR & $\mathrm{SD}$ & $\mathrm{Z} / \mathrm{X}^{2}$ & $\mathrm{P}$ \\
\hline \multirow[t]{2}{*}{ Objectives } & Male & 1124.21 & \multirow[t]{2}{*}{7.774} & \multirow[t]{2}{*}{-7.095} & \multirow[t]{2}{*}{$.000 * *$} \\
\hline & Female & 1376.53 & & & \\
\hline \multirow[t]{2}{*}{ Content } & Male & 1087.60 & \multirow[t]{2}{*}{7.061} & \multirow[t]{2}{*}{-8.033} & \multirow[t]{2}{*}{$.000 * *$} \\
\hline & Female & 1398.85 & & & \\
\hline \multirow[t]{2}{*}{ Implementation } & Male & 1165.87 & \multirow[t]{2}{*}{9.685} & \multirow[t]{2}{*}{-3.786} & \multirow[t]{2}{*}{$.000^{* *}$} \\
\hline & Female & 1359.43 & & & \\
\hline \multirow[t]{2}{*}{ Evaluation } & Male & 1274.55 & \multirow[t]{2}{*}{3.319} & \multirow[t]{2}{*}{-.112} & \multirow[t]{2}{*}{.736} \\
\hline & Female & 1289.82 & & & \\
\hline
\end{tabular}

$(* \mathrm{P}<.05 ; * * \mathrm{P}<.01)$

The reason why the differences are significant is that female students have lower instrumental motivations than male students, but their integrative motivations are stronger. According to motivation theories, learners who have stronger instrumental motivations are simple and single in learning style, language input and output. For example, those who aim to pass the examination would enhance their exam-taking abilities by doing a lot of exercises. By comparison, learners who have stronger integrative motivations tend to study English in various ways due to their interests in English and other reasons. Thus, the results in the study effectively verified relevant theories on learning motivation.

Differences in Learners' Needs of Students with Different Language Proficiencies. As mentioned in research methodology, the students are divided into three groups (Group A, B, C) according to their scores in the entrance proficiency test of English. From Table 4, students exhibit 
significant differences in learners' needs of teaching materials $(\mathrm{P}=0.000)$, which mainly embodies in enriching listening and speaking textbooks, expanding the teaching content of listening, speaking, reading, writing and cultures of English-speaking countries. Furthermore, compared with students in group B (intermediate level proficiency) and group C (low level proficiency), students in Group A (high level proficiency) have higher needs in the following aspects: listening materials of great diversity and variety, abundant English reading materials, oral English practice, more cultural background knowledge of english speaking countries and related materials in English writing. Therefore, college students' language proficiency is an important influencing factor in choosing curriculum content. The higher the learners’ language proficiencies are, the greater English learning materials are needed, especially those of abundant and pluralistic content.

Table 4. Differences in Learners’ Needs of Students with Different Proficiencies

\begin{tabular}{|c|c|c|c|c|c|c|}
\hline & Group & $\mathrm{N}$ & $\mathrm{MR}$ & $\mathrm{SD}$ & $\mathrm{Z} / \mathrm{X}^{2}$ & $\mathrm{P}$ \\
\hline \multirow{3}{*}{$\begin{array}{c}\text { Needs of } \\
\text { Teaching Materials }\end{array}$} & & 568 & & 5.121 & 21.798 & $.000^{* *}$ \\
\cline { 2 - 7 } & $\mathrm{A}$ & 96 & 1357.69 & & & \\
\cline { 2 - 7 } & $\mathrm{B}$ & 371 & 1310.37 & & & \\
\cline { 2 - 7 } & $\mathrm{C}$ & 101 & 1093.45 & & & \\
\cline { 2 - 7 } $\begin{array}{c}\text { Needs of } \\
\text { Media Resources }\end{array}$ & $\mathrm{A}$ & 968 & 1268.82 & & & \\
\cline { 2 - 7 } & $\mathrm{B}$ & 371 & 1265.51 & & & \\
\cline { 2 - 8 } & $\mathrm{C}$ & 101 & 1227.93 & & & \\
\hline
\end{tabular}

$(* \mathrm{P}<.05 ; * * \mathrm{P}<.01)$

Differences in Learners' Needs of Students with Different Majors. The resluts in the study show there are significant differences among students with different majors in their needs of college English curriculum $(\mathrm{P}=0.021)$, especially the objectives and content. On the one hand, different majors have different requirements of students' English capabilities; on the other hand, students of different majors would take different amounts of time to study English. Majors concerning foreign affairs or foreign nationals like international trade and majors closely related to high-tech like information technology may have relatively high requirements of students' language proficiencies in English.

1. Further analyses reveal that the differences in students' needs of teaching materials focus on listening and speaking, writing and English cultural teaching. To a certain extent, due to their 
different major requirements and personal developments, students' needs of the above teaching materials in school of economics and management is the biggest ( $\mathrm{MR}=1396.77)$ while school of architectural engineering is the smallest ( $M R=1001.35)$. What's more, the differences in students' needs of media resources highlight audio-visual materials and English learning websites. For the reason that they should spend a lot of time on professional knowledge and skills and try to take advantage of those media resources to improve their English study efficiency, students in school of information and electrical engineering have the biggest needs of media resources ( $\mathrm{MR}=1381.64)$. In contrast, students' needs of media resources in school of humanities and arts is the smallest ( $M R=1004.32$ ) because they have more time to balance their study between specialized courses and English courses.

\section{Conclusion}

The study indicates that curriculum setting is a circular interaction including curriculum objectives, content, implementation and evaluation. Among them, learners' needs analysis is one of the crucial elements. For one thing, college English curriculum setting provides the students with abundant learning resources; for another, requirements of different students would react on curriculum setting in the teaching practice. In detail, the major findings of this study can be summarized as follow and some implications can be offered for college English teaching accordingly:

Apart from curriculum evaluation, the differences between male students and female students in the needs of college English curriculum objectives, content and implementation are significant. And those needs for females are obviously stronger than males. Thus, teachers should take gender into account in college English curriculum setting and enforcement, refine teaching methods from individual to individual.

For students with different language proficiencies (Group A, B, C), there are significant differences in learners' needs of teaching materials. And high level proficiency students have stronger needs than low level proficiency students in those content of abundance and variety. As a result, students should be taught in accordance of their aptitude and grade teaching has been the trend 
of college English teaching reform in recent years. In the meantime, it is necessary to set up some elective courses for different majors, providing more opportunities for students to improve their English.

The differences among students with different majors in their needs of curriculum objectives and content are significant, however, there is no significant differences in curriculum implementation and evaluation. To meet the individual and diverse needs of students with different majors, teachers should get to the root of the matter, set multi-level curriculum objectives and optimize curriculum setting, hence, the studnets' learning points and efforts would be centered on in the future.

\section{References}

[1] B. B. Chen. Theory Construction of Analytical Framework of Needs Analysis in College English [J]. Foreign Languages Research, 2010, (2): 120-123.

[2] B. H. Wang \& H. Liu. Learners' Needs Analysis of College English and Its Implications [J]. Foreign Language Teaching Abroad, 2003, (3): 34-38.

[3] Dudley-Evans \& St John. Developments in English for Specific Purposes: A Multi-disciplinary Approach [M]. Cambridge: Cambridge University Press, 1998.

[4] Hutchinson T \& Waters A. English for Specific Purposes: A Learning-centered Approach [M]. Cambridge: Cambridge University Press, 1987.

[5] H. X. Wang. Needs and Requirements in Personalized College English Syllabus Design [J]. Foreign Languages in China, 2004, (1): 21-26.

[6] Q. F. Wen. Opportunities and Challenges of College English Teaching Based on Curriculum theories [J]. Foreign Language Teaching and Research, 2012, (3): 283-292.

[7] Q. H. Zhao \& L. Lei \& M. Zhang. College English Teaching from Students' Perspective in English Study Needs [J]. Foreign Language World, 2009, (4): 12-22.

[8] R. Liu \& L. X. Zhang \& P. F. Yan. Needs Analysis of College Undergraduates Academic English [J]. Education Review, 2014, (3): 78-80. 
[9] W. H. Yu. The Role of Needs Analysis in Foreign Language Teaching [J]. Foreign Languages and Their Teaching, 2002, (8): 20-23.

[10] X. B. Yang. Learners' Needs Analysis of College English Curriculum During the Period of Transformation [J]. Journal of Hubei University, 2013, (7): 27-34.

[11] Y. Leng. Graded English Teaching Reform in College Based on Needs Analysis Theories [J]. Hebei Normal University Journal, 2009, (11): 123-127.

[12] Y. M. Liu \& H. M. Zhu. College English Curriculum Settings Based on Learners’ Needs Analysis [J]. Shandong Foreign Languages Teaching Journal, 2013, (3): 69-76. 